\author{
Research Article \\ www.ijrap.net (ISSN:2229-3566)
}

\title{
INCIDENCE OF CONSANGUINITY IN INDIAN CHILDREN WITH CEREBRAL PALSY: A SURVEY STUDY
}

Rashmi HA ${ }^{1}$, Shailaja U ${ }^{* 2}$, Prasanna N Rao ${ }^{3}$

${ }^{1}$ Student, SDM College of Ayurveda and Hospital, Hassan, Karnataka, India

${ }^{2}$ Professor and Head, Department of Kaumarabhritya, SDM College of Ayurveda and Hospital, Hassan, Karnataka, India

${ }^{3}$ Principal and Chief Medical Officer, SDM College of Ayurveda and Hospital, Hassan, Karnataka, India

Received on: 19/04/21 Accepted on: 18/06/21

\author{
*Corresponding author \\ E-mail: rao.shaila@gmail.com
}

DOI: $10.7897 / 2277-4343.120370$

\begin{abstract}
Cerebral palsy is a non-progressive neurodevelopmental disorder. Cerebral palsy is 2.5 times higher in consanguineous marriage due to autosomal recessive transmission. In India, the estimated incidence is 3 per 1000 live births. The objective of this study is to evaluate the incidence of consanguinity in children with cerebral palsy and measures taken to create awareness. A survey study in the form of semi structured interview was conducted by eliciting the history from the parents of 50 cerebral palsy children in Hassan, Bangalore and Udupi within the period of 3 months using pretested questionnaires, where cerebral palsy patient's cases were taken and symptoms, age of their parents, presence of consanguinity and its degree were noted and compared with other neurological and genetic conditions to exclude them. Thus obtained results were tabulated and analysis is done by statistical method. It was found that, the incidence rate of consanguinity in children with Cerebral palsy is $18 \%$. And $22 \%$ of cases presented with dysmorphism, which suggests multiple genetic factors in the form of autosomal recessive gene mutation contributing for Cerebral palsy. Findings suggests that the incidence rate of consanguinity in children with Cerebral palsy is $18 \%$ those children also presented with dysmorphism, so when these two are taken into consideration we can conclude that consanguinity as a risk factor for cerebral palsy.
\end{abstract}

Keywords: consanguinity, cerebral palsy, neurodevelopmental disorder

\section{INTRODUCTION}

Cerebral palsy $(\mathrm{CP})$ is a disorder impairing movement as a result of a defect or lesion in the developing brain. Symptoms become apparent within the first few years of life and generally do not worsen over time. ${ }^{1}$ it contributes a major share in childhood illness with an incidence of 1 in 250 to $1,000 \cdot^{2-3}$ The cause of Cerebral palsy is often hard to determine but about $10-15 \%$ of cases appear to be due to intrapartum problems. ${ }^{5}$ The other major risk factors are prematurity, small size for gestational age, and multiple births. ${ }^{6}$ Inherited factors are thought to contribute to approximately $2 \%$ of cases in European populations; ${ }^{1,7}$ neonatal brain disorders when understood in the light of genetic patterns, it is clear that de novo mutations and recessive disorders can often simulate "non-genetic" conditions.

Consanguinity means the amount of shared identical DNA. Worldwide the commonest form of consanguinity is between first cousins, where each of them pools $1 / 8^{\text {th }}$ of their genes as they have a common ancestor thereby risking the offspring of consanguineous marriage to a certain genetic disorders. Various autosomal recessive genes run with in families. So, there are chances of transmitting this gene to their off springs in marriages between relatives but, the severity depends on the extent of genetic relationship between parents. There are 4 degrees such as (i) First degree - parent child relationship (ii) Second degree sibling relationship (iii) Third degree - uncle/aunt with niece/nephew (iv) Fourth degree - between first cousins

Objective: To evaluate the incidence of consanguinity in children with Cerebral palsy

\section{MATERIALS AND METHODS}

Case proforma was prepared in order to take 50 cerebral palsy cases. The case sheet included; Vital data, Signs and symptoms of cerebral palsy with its classification, Birth history of prenatal, perinatal and postnatal, Specific history on consanguineous marriage and its degree, Pedigree chart, Family history, Anthropometry, Dysmorphism. The study is carried out as per International conference of Harmonization-Good Clinical Practices Guidelines (ICH-GCP) or as per Declaration of Helsinki guidelines.

Type of research: A survey study was conducted in the form of semi structured interview at the hospitals.

Source of study: Indira Gandhi Institute of Child Health (IGICH), Bengaluru, Sri Dharmasthala Manjunatheshwara College of Ayurveda and Hospital, Hassan, Hassan Institute of Medical Science, Hassan and Sri Dharmasthala Manjunatheshwara College of Ayurveda, Udupi, Karnataka, India.

The sample size of research study is 50

\section{Diagnosis}

A thorough history was taken regarding prenatal, perinatal and postnatal, family history including presence of consanguinity, its degree; age of parents was also noted. Physical examination was also done to note the types of cerebral palsy so to exclude other progressive disorders of the CNS including degenerative disease like muscular dystrophies, neurometabolic diseases and genetic disorders like Down syndrome. 


\section{RESULTS}

Result of survey study conducted on 50 cases is as follows;

Consanguinity was present in 9 cases where as 41 were born out of non-consanguineous marriage. 42 cases were of spastic cerebral palsy, 7 were ataxic and 1 was dyskinetic. 23 were caused due to birth asphyxia, 15 were due to seizures, 8 out of PRM and 4 were others. Dysmorphism was present 11 cases.

Table 1: Number of Cerebral palsy children presented with consanguinity

\begin{tabular}{|c|c|c|}
\hline & n & $\mathbf{\%}$ \\
\hline Total number of cases & 50 & $100 \%$ \\
\hline Presence of consanguinity & 9 & $19 \%$ \\
\hline Absence of consanguinity & 41 & $82 \%$ \\
\hline
\end{tabular}

Table 2: Types of cerebral palsy

\begin{tabular}{|c|c|c|}
\hline & n & $\mathbf{\%}$ \\
\hline Total number cerebral palsy cases & 50 & $100 \%$ \\
\hline Spastic cerebral palsy & 42 & $84 \%$ \\
\hline Ataxic cerebral palsy & 7 & $14 \%$ \\
\hline Dyskinetic cerebral palsy & 1 & $2 \%$ \\
\hline
\end{tabular}

Table 3: Causes of cerebral palsy

\begin{tabular}{|c|c|c|}
\hline & $\mathbf{n}$ & $\mathbf{\%}$ \\
\hline Total number of cases & 50 & 100 \\
\hline Birth asphyxia & 23 & 46 \\
\hline Seizers & 15 & 30 \\
\hline Pre mature rupture of membrane & 8 & 16 \\
\hline Others & 4 & 8 \\
\hline
\end{tabular}

Table 4: Presence of dysmorphism

\begin{tabular}{|c|c|c|}
\hline & n & \% \\
\hline Total number of cases & 50 & 100 \\
\hline Presence of dysmorphism & 11 & 22 \\
\hline Absence of dysmorphism & 39 & 78 \\
\hline
\end{tabular}

\section{Statistical analysis}

Among 9 cases with presence of consanguinity 8 cases had $4^{\text {th }}$ degree of consanguinity and 1 case had $3^{\text {rd }}$ degree of consanguinity. Out of 11 cases of dysmorphism in cerebral palsy, 5 children have shown presence of consanguinity. A cerebral palsy child with $3^{\text {rd }}$ degree consanguinity had seizure as aetiology and also presented microcephaly (dysmorphism). Cerebral palsy children with $4^{\text {th }}$ degree of consanguinity, 3 cases had birth asphyxia and 5 cases had seizure as aetiology. 9 cerebral palsy cases with presence of consanguinity had 5 spastic type of cerebral palsy, 3 ataxic type of cerebral palsy and 1 with dyskinetic type of cerebral palsy. Out of 42 spastic cerebral palsy, 4 cases were monoplegia, 11 cases were hemiplegic, 15 cases were diplegic and 10 cases were quadriplegic

\section{DISCUSSION}

The etiology of cerebral palsy may vary from country to country and population-specific factors of cultural relevance such as consanguinity are important to investigate. One of the main objectives of our study was to see if there was an association between cerebral palsy and consanguinity. The results of the study showed that $18 \%$ of cases were from consanguineous parents $\left(1^{\text {st }}\right.$ or $2^{\text {nd }}$ cousins). As per previous researches consanguinity was found to be a top risk factor. ${ }^{1}$ Available research into a genetic link to cerebral palsy is mostly in the form of small-scale studies and case reports. ${ }^{3-4}$ Among etiologies of cerebral palsy genetic causes accounts for $1-2 \%$ and it is understood that causes of cerebral palsy could be genetic as well as result of environmental factors that lead to any insult to developing CNS. ${ }^{5}$ With $60 \%$ of cerebral palsy cases having an unknown cause other than suspected pre-partum risk factors ${ }^{6}$. A study conducted recently states that pre-puberty death of off springs born to first cousins where $4.4 \%$ higher than their nonconsanguineous counter parts, in over 600,000 pregnancies and live births. ${ }^{9}$ A recent study in Qatar showed that mental retardation, epilepsy was significantly more common in offspring of consanguineous couples. ${ }^{8}$ The high mortality rate in developing countries, associated with consanguinity, largely occurs within the first year of birth. ${ }^{10-12}$ An obvious correlation between consanguinity and autosomal recessive disease was evident where the diagnosis was possible. ${ }^{13-16}$ Several deaths have also been reported in a proportion of consanguineous families in developing countries. ${ }^{17}$ If genetic testing is included as a part of diagnostic tool of individuals with suspected cerebral palsy, which makes cerebral palsy gene discovery a challenging task.

\section{CONCLUSION}

Cerebral palsy is the most common physical disability in children with non-progressive neurodevelopmental disorders. Despite being commonly attributed to a range of environmental factors, particularly birth asphyxia, specific cause of cerebral palsy remains unknown in most individuals. A growing body of evidence suggests that cerebral palsy is probably caused by multiple genetic factors including consanguinity as well. Consanguineous marriages have been practiced since the early existence of modern humans. The present study was undertaken to analyze the effect of consanguinity on different types of cerebral palsy. $18 \%$ of cerebral palsy children had history of consanguinity and $22 \%$ of children presented with dysmorphism, which suggests that, the involvement of genetic factor in cerebral palsy. Genetic evaluation should be considered in patients with congenital malformations (chromosomes) due to consanguinity, as the offspring of consanguineous unions may be at increased risk to genetic disorders because of expression of autosomal recessive gene mutation.

\section{ACKNOWLEDGEMENT}

Authors thank Rajiv Gandhi University of Health Sciences, Karnataka for the monetary support and also acknowledge the guidance of Dr. Venkatesh GS, Director, Advance Research, Rajiv Gandhi University of Health Sciences and Karnataka. Authors also acknowledge the support of Dr. Vykuntaraju KN, Associate Professor of Pediatric neurology, Indira Gandhi Institute of Child Health, Bengaluru and Research committee, SDM College of Ayurveda and Hospital, Hassan.

\section{REFERENCES}

1. Suvanand S, Kapoor SK, Reddaiah VP, Singh U, Sunda-ram KR. Risk factors for cerebral palsy. Indian J Paediatr 1997; 64(5): 677-85.

2. Shankaran S. Prevention, diagnosis and treatment of cerebral palsy in near-term and term infants. Clin Obstet Gynaecol 2008; 51(4): 829-39.

3. Keogh JM, Badawi N. The origins of cerebral palsy. Curr Opin Neurol 2006 Apr; 19(2): 129-34.

4. Stanley F, Blair E, Alberman E, editors. Cerebral palsies: epidemiology and causal pathways. Cambridge: Cambridge University Press; 2000.

5. Hamamy $H$. Consanguineous marriages, preconception consultations in primary health care settings. J Community Genet 2012 Jul; 3(3): 185-92.

6. Assaf S, Khawaja M. Consanguity trends and correlates in the Palestinian Territories. J Biosoc Sci 2009 Jan; 41(1): 107-24. 
PMID: 18549512

7. Hamamy H, Antonarakis SE, Cavalli-Sforza LL, Temtamy S, Romeo G, Kate LP, et al. Consanguineous marriages, pearls and perils: Geneva International Consanguinity Workshop Report. Genet Med. 2011 Sep; 13(9): 841-7.

8. Erkin G, Delialioglu SU, Ozel S, Culha C, Sirzai H. Risk factors and clinical profiles in Turkish children with cerebral palsy: analysis of 625 cases. Int J Rehabil Res 2008 Mar; 31(1): 89-91.

9. Menkes J, Flores-Sarnat L. Cerebral palsy due to chromosomal anomalies and continuous gene syndrome. Clin Perinatol 2006; 33: 481-501.

10. Kuban K, Leviton A. Cerebral palsy. N Engl J Med 1994; 330: 188-95.

11. Barnes C, DeVaber G. Prothombic abnormalities in childhood ischemic stroke. Thromb Res 2006; 118: 67-74.

12. Verschuuren-Bemelmans CC, Winter P, Sival DA, Elting JW, Brouwer OF, Mûller U. Novel homozygous ALS2 nonsense mutation (p. Gln 715X) in sibs with infantile-onset ascending spastic paralysis: the first cases from northwestern Europe. Eur J Hum Genet 2008 Nov; 16(11): 1407-11.

13. Afrooz Gh. Principles and methods of prevention of disabilities. $1^{\text {st }}$ ed. Tehran: Tehran University Publications;
2006.

14. Durkin MS, Khan NZ, Davidson LL, Huq S, Munir S, Rasul $\mathrm{E}$, et al. Prenatal and postnatal risk factors for mental retardation among children in Bangladesh. Am J Epidemiol 2000; 152(11):1024-33.

15. Movaffagh A, Haji Seyed Javadi M, Hashemi SZ, Azargashb E, Ghasemi Barghi R. Prevalence of congenital abnormalities in familial and non-familial marriage. Pejouhandeh 2007; 12(2): 129-34.

16. World Health Organization. Department of Measurement and Health Information. [Online] 2007. [Cited 2007 Dec].

17. McClure EM, Saleem S, Pasha O, Goldenberg RL. Stillbirth in developing countries: a review of causes, risk factors and prevention strategies. J Matern Fetal Neonatal Med 2009; 22(3): 183-90.

\section{Cite this article as:}

Rashmi HA et al. Incidence of Consanguinity in Indian children with Cerebral Palsy: A Survey Study. Int. J. Res. Ayurveda Pharm. 2021;12(3):38-40 http://dx.doi.org/10.7897/2277$\underline{4343.120370}$

Disclaimer: IJRAP is solely owned by Moksha Publishing House - A non-profit publishing house, dedicated to publishing quality research, while every effort has been taken to verify the accuracy of the content published in our Journal. IJRAP cannot accept any responsibility or liability for the site content and articles published. The views expressed in articles by our contributing authors are not necessarily those of IJRAP editor or editorial board members. 